\title{
STRATEGI KOMUNIKASI KOMISI PEMILIHAN UMUM (KPU) KABUPATEN BANGKALAN DALAM MENINGKATKAN PARTISIPASI MASYARAKAT
}

\author{
Siti Zaenab ${ }^{1}$, Nikmah Hadiati Salisah ${ }^{1}$ \\ ${ }^{1-2}$ Universitas Islam Negeri Sunan Ampel Surabaya \\ 1'zaenab159@gmail.com, ${ }^{2}$ hadiati@gmail.com
}

\section{Article Info}

\section{Article history:}

Received 14 Februari 2019

Accepted 12 Maret 2019

Published 10 April 2019

\section{Keyword:}

Strategi Komunikasi,

Pemilihan Kepala

Daerah, Komisi Pemilihan

Umum

\section{Abstract}

This research discusses how the communication strategy of the General Election Commission (KPU) of Bangkalan Regency to increase public participation in regional head elections. This study uses a qualitative approach to investigate more deeply the observed focus. The theory used is strategic planning theory. The results of this study are (1) the communication strategy of the Bangkalan Regency's KPU to increase voter participation using conventional methods, (2) the beginner voter education strategy is one of the KPU strategies by paying special attention to first-time voters. They are high school students/equivalent, by cooperating with novice voters.

Penelitian ini membahas tentang bagaimana strategi komunikasi Komisi Pemilihan Umum (KPU) Kabupaten Bangkalan untuk meningkatkan partisipasi masyarakat dalam pemilihan umum kepala daerah. Penelitian ini menggunakan pendekatan kualitatif untuk menyelidiki secara lebih mendalam terhadap fokus yang diamati. Teori yang digunakan adalah teori perencanaan strategis. Hasil penelitian ini adalah (1) strategi komunikasi KPU Kabupaten Bangkalan untuk meningkatkan partisipasi pemilih lebih menggunakan cara konvensional, (2) strategi pendidikan pemilih pemula merupakan salah satu strategi KPU dengan memberikan perhatian secara khusus kepada pemilih pemula. Mereka adalah para pelajar SLTA/sederajat, dengan menggandeng pemilih pemula.

\section{Editorial Office:}

Program Studi Ilmu Komunikasi, Fakultas Dakwah dan Komunikasi, UIN Sunan Ampel Surabaya. Jl. Ahmad Yani 117 Surabaya, Jawa Timur, Indonesia.

Email: jurnalilkom@uinsby.ac.id 


\section{Pendahuluan}

Pada masa kepemerintahan JokowiJusuf Kalla, pemilihan umum dikemas dalam pemilihan serentak. Artinya, Indonesia melakukan pemilihan serentak baik dalam pemilihan presiden maupun kepala daerah secara bersamaan dalam waktu dan tanggal yang sama. Pemilihan kepala daerah secara serentak dilaksanakan sesuai amanat Undang-Undang No 8 Tahun 2015 tentang Pemilihan Gubernur, Bupati, dan Wali Kota. Dalam UndangUndang tersebut dijelaskan bahwa pemilihan gubernur, bupati, dan wali kota dilaksanakan secara serentak dan bertujuan untuk menghemat anggaran Negara. ${ }^{1}$

Tentu, butuh kerja keras dan usaha yang kreatif dalam mengajak masyarakat untuk bisa berperan aktif dalam PEMILU khususnya PILKADA. Karena suara rakyat adalah penentu sang pemimpin. Menghadapi masyarakat yang majemuk dengan banyak varian karakter tidaklah mudah terutama dalam masyarakat awam. Butuh proses dan pendekatan sosial untuk membangkitkan antusiasme masyarakat dalam PILKADA. Masih banyak dari masyarakat kita yang tidak mau ikut berpartisipasi dalam PILKADA karena banyak faktor, khususnya di Bangkalan. Hal ini sudah menjadi problematika setiap tahun politik tiba.

Proses pemilihan umum di Kabupaten Bangkalan menjadi salah satu kontestasi demokrasi yang paling disoroti oleh pemerintah pusat, sebab Bangkalan termasuk ke dalam zona merah, alasanya

1 Tjahjo Kumolo, Politik Hukum Pilkada Serentak, (Jakarta: Mizan Republika, 2015), 82.

2 Jppn.com, "Jelang Coblosan Polisi Massa Bentrok, 20 September 2020), terjadi kala Pemilu 2012 Bulan Desember Tanggal 12.

Keputusan KPU Bangkalan yang mendiskualifikasi pasangan calon Imam Buchori-HR Zainal Alim (Imam-Zein). Dampak dari diskualifikasi tersebut suasana Bangkalan, Madura, semakin panas. terjadi bentrokan antara aparat keamanan dan massa pendukung Imam Buchori-Zainal Alim (Zein), pasangan calon yang telah dicoret KPU Bangkalan. Bentrokan terjadi di sekitar Kantor KPU Bangkalan, Jalan Pemuda Kaffa, Bangkalan. Kericuhan pecah setelah KPU mengeluarkan logistik dari gudang untuk didistribusikan. $^{2}$

Berkat kericuhan tersebut, kinerja KPU sebagai penyelenggara menjadi semakin sulit, pertarungan citra, kapabilitas dan asas ketidakberpihakan menjadi modal utama KPUD Bangkalan untuk menarik antusiasme masyarakat untuk tetap datang ke tempat pemungutan suara. KPU sebagai penyelenggara Pemilu terus melakukan upaya guna meningkatnya taraf partisipasi aktif yang hadir ke tempat pemungutan suara. Salah satu strateginya ialah KPU terus berupaya mensosialisasikan hari pencoblosan.

Meski begitu, di Tahun 2012 dengan jumlah Daftar pemilih tetap sebanyak 888.928 suara, tingkat partisipasi masyarakat menyentuh angka 64,78 persen. $^{3}$ Tingkat partisipasi itu dapat terbilang cukup sukses setelah rentetan kejadian yang terus menerus menurunkan

https://pilkada.jpnn.com/news/jelang-coblosanpolisi-massa-bentrok.

${ }^{3}$ Berdasarkan data rekapitulasi KPU Tahun 2012. 
tingkat kepercayaan masyarakat pada KPUD Bangkalan.

Sementara pada Tahun 2018, KPUD Bangkalan bekerja normal tanpa hambatan yang berarti, di tahun itu, jumlah daftar pemilih tetap memang terbilang menurun, alasanya tentu tingkat populasi masyarakat yang berkurang berdasarkan data dari dinas kependudukan dan catatan sipil setempat. sebanyak 859.067 pemilih tercatat dalam data KPUD Kabupaten Bangkalan dengan tingkat partisipasi masyarakat telah meningkat menyetuh angka 65.29 persen. ${ }^{4}$

Seiring dengan perkembangan zaman, dan teknologi yang semakin berkembang, pola strategi danpendekatan KPU terhadap pemilih pun lebih menyesuaikan. Contoh sederhanya, pada tahun 2012, perkembangan media sosial tak sepesat tahun 2018, sehingga model dan strategi KPU terkesan lebih konservatif dan monolog. (pemilih segmen nitizen)

Peningkatan pemilih dimaksudkan untuk meningkatkan partisipasi pemilih, partisipasi keterlibatan pemilih pada periode sebelum pemilihan. Namun pada tahun ini, dengan perkembangan media sosial, KPU mampu membuka ruang diskusi publik dalam media sosial, seperti facebook, twitter, whatshap, instagram, dan media sosial yang lainya.

Untuk meningkatkan partisipasi masyarakat KPU melakukan sosialisasi terhadap masyarakat setempat untuk menyadarkan bahwa berpartisispasi dalam PILKADA sangat dibutuhkan untuk menentukan calon pemimpin yang terbaik.

\footnotetext{
${ }^{4}$ Berdasarkan data rekapitulasi KPU Tahun 2018
}

Artinya, sosialisasi yang sering dilakukan pihak KPU adalah demi kesejahteraan bersama. Namun, banyak masyarakat yang tidak mau ikut andil dalam pemilihan. Oleh karena itu dalam sosialisasi butuh komunikasi yang baik dengan masyarakat. Dimana dari komunikasi tersebut dapat meningkatkan partisipasi masyarakat. Komunikasi itu sendiri menurut Raymond Ross "Komunikasi adalah suatu proses menyortir, memilih, dan mengirimkan simbol-simbol sedemikian rupa sehingga membantu pendengar membangkitkan makna atau respon dari pemikiran yang serupa dengan yang dimaksudkan oleh komunikator."5 Tidak hanya cukup memahami apa itu komunikasi, namun KPU juga membutuhkan sebuah strategi komunikasi untuk dapat mengambil perhatian masyarakat supaya partisipasi masyarakat meningkat.

Dari latar belakang masalah tersebut, maka penting kiranya peneliti ingin mengupas perjalanan KPUD Kabupaten Bangkalan mengembalikan citra dan taraf kepercayaan masyaramat sebagai pemiih dengan judul penelitian 'strategi Komunikasi Kpu Bangkalan Dalam Meningkatkan Partisipasi Masyarakat Pada Pelaksanaan Pilkada Serentak', dengan judul "Bagaimana strategi komunikasi KPU Kab. Bangkalan dalam meningkatkan partisipasi masyarakat Bangkalan pada PILKADA Bangkalan 2018."

5 Dedy Mulyana, Ilmu Komunikasi Suatu Pengantar, (Bandung: Remaja Rosdakarya, 2010), 68. 


\section{Kajian Pustaka}

\section{Strategi Komunikasi}

Kata strategi berasal dari bahasa yunani klasik, yaitu 'stratos"' yang artinya tentara dan 'agein' yang berarti memimpin. Dengan demikian, strategi dimaksudkan adalah memimpin tentara. ${ }^{6}$ Lalu muncul kata strategos yang artinya pemimpin tertara tingkat atas. Jadi strategi adalah konsep militer yang bisa diartikan sebagai strategi perang (the art of general), atau suatu rancangan terbaik untuk memenangkan peperangan. Dalam strategi ada prinsip yang harus dicampakan, yakni "tidak ada sesuatu yang berarti dari segalanya kecuali apa yang akan dikerjakan oleh musuh, sebelum mereka mengerjakannya',

Karl Von Clausewis (1780-1831) seorang pensiunan jendral prusia dalam bukunya on war merumuskan strategi ialah "suatu seni menggunakan sarana pertemuran untuk mencapai tujuan perang,",7 secara garis besar strategi menghasilkan gagasan dan konsepsi yang dikembangkan oleh para praktisi. Karena itu para pakar strategi tidak saja lahir dari kalangan berlatar belakang militer, tetapi juga dari profesi lain. Dalam mengangani maslah komunikasi, para perencana dihadapakan pada sejumlah persoalan, terutama dalam kaitannya dengan strategi penggunaan sumber daya

\footnotetext{
${ }^{6}$ Hafied Cangara, Perencanaan dan Strategi Komunikasi, (Jakarta: PT. Raja Grasindo), 28.

${ }^{7}$ Hafied Cangara, Perencanaan, 29.
}

komunikasi yang tersedia untuk mencapai yang ingin dicapai. ${ }^{8}$

Dalam menangani masalah komunikasi, para perencana dihadapkan kepada beberapa persoalan terutama dalam penggunaan sumber daya komunikasi yang tersedia untuk mencapai tujuan tertentu yang ingin dicapai. Rogers (1982) memberi batasan pengertian strategi komunikasi sebagai suatu rancangan yang dibuat untuk mengubah tingkah laku seseorang dalam skala besar melalui ide-ide baru. Dalam artian khususnya, strategi komunikasi adalah kombinasi yang terbaik dari semua elemen komunikasi mulai dari komunikator, pesan, media, penerima sampai pada pengaruh (efek) yang dirancang untuk mencapai tujuan komunikasi yang optimal, sebab pemilihan strategi komunikasi menjadi hal yang paling krusial dan memerlukan ketelitian dalam proses perencanaan strategi komunikasi.

Strategi dalam komunikasi adalah cara mengatur pelaksanaan oprasi komunikasi agar berhasil. Strategi komunikasi pada hakikatnya adalah perencanaan (planning) dan manajemen (magement) untuk mencapai satu tujuan. Untuk mencapai tujuan tersebut, strategi tidak berfungsi sebagai peta jalan yang hanya menunjukkan arah, tetapi juga harus menunjukkan taktik oprasionalnya. Oleh karenanya dari

${ }^{8}$ Onong Uchjana Effendy, Ilmu Komunikasi Teori dan Praktek, (Bandung: Remadja Karya,1984), 18. 
paparan secara teori diatas, agar komunikator Pada saat berkomunikasi harus bisa membuat strategi komunikasi terlebih dahulu agar pesan yang kita sampaikan bisa mencapai target komunikasi yang diinginkan. Komunikasi adalah proses penyampaian suatu pesan dalam bentuk simbol atau kode dari dari satu pihak kepada yang lain dengan efek untuk mengubah sikap, atau tindakan. (Sorensen, 2003:21). ${ }^{9}$

\section{Komisi Pemilihan Umum}

Komisi Pemilihan Umum adalah lembaga negara yang menyelenggarakan pemilihan umum di Indonesia, yakni meliputi Pemilihan Umum Anggota DPR/DPD/DPRD, Pemilihan Umum Presiden dan Wakil Presiden, serta Pemilihan Umum Kepala Daerah dan Wakil Kepala Daerah. Komisi Pemilihan Umum tidak dapat disejajarkan kedudukannya dengan lembagalembaga negara yang lain yang kewenangannya ditentukan dan diberikan oleh UUD 1945.

Dalam Pasal 10 Undang-undang Nomor3 Tahun 1999 tentang Pemilihan Umum dan Pasal 2 Keputusan Presiden Nomor 16 Tahun 1999 tentang Pembentukan Komisi Pemilihan Umum dan Penetapan Organisasi dan Tata Kerja Sekretariat Umum Komisi Pemilihan Umum, dijelaskan bahwa untuk melaksanakan
Pemilihan Umum, KPU mempunyai tugas kewenangan merencanakan, menerima, meneliti, menetapkan, dan membentuk panitia pemengutan suara, menetapkan anggota Dprd, Bupati/Wali Kota Serta Presiden.

Dari pengertian di atas dapat disimpulkan, bahwa pemilihan umum adalah proses pemilihan atau penentuan sikap yang dilakukan oleh suatu masyarakat untuk memilih penguasa ataupun pejabat politik untuk memimpin suatu Negara yang juga diselenggarakan oleh Negara.

Hak Pilih dalam Pemilu Pada azasnya setiap warga negara berhak ikut serta dalam Pemilihan Umum. Hak warganegara untuk ikut serta dalam pemilihan umum disebut Hak Pilih, yang terdiri dari:

a) Hak pilih aktif (hak memilih)

b) Hak pilih pasif (hak dipilih)

Setiap warga negara Indonesia yang pada hari pemungutan suara sudah berumur tujuh belas tahun atau lebih atau sudah/pernah kawin, mempunyai hak memilih. Seorang warga negara Indonesia yang telah mempunyai hak memilih, baru bisa menggunakan haknya, apabila telah terdaftar sebagai pemilih. ${ }^{10}$ Seseorang yang telah mempunyai hak memilih, untuk dapat terdaftar sebagai pemilih, harus memenuhi persyaratan; tidak terganggu jiwa/ ingatannya dan tidak sedang dicabut hak pilihnya berdasarkan putusan Pengadilan yang

\footnotetext{
${ }^{9}$ www.kpu.go.iddi, 30 Desember 2018.

10 Abdullah Rozali, Mewujudkan Pemilu yang Lebih Berkualitas Pemilu Legislatif, (Jakarta: PT. Raja Grafindo Persada, 2009), 168.
} 
telah mempunyai kekuatan hukum tetap, sebaliknya seorang warga negara Indonesia yang telah terdaftar dalam Daftar Pemilih Tetap (DPT), kemudian ternyata tidak lagi memenuhi persyaratan tersebut di atas, tidak dapat menggunakan hak memilihnya.

\section{Pilkada Serentak}

Pemilihan Umum Kepala Daerah atau yang biasa disingkat dengan PEMILUKADA atau PILKADA adalah pemilihan umum untuk memilih Kepala Daerah dan Wakil Kepala Daerah secara langsung di Indonesia oleh penduduk daerah setempat yang memenuhi syarat. ${ }^{11}$ PILKADA serentak adalah pemilihan umum secara bersamaan seperti pemililhan presiden, gubernur, bupati, walikota, DPRD/DPR RI yang dilaksanaan seacara serentak dalam hari yang sama. Hal ini sebagaimana telah dijelaskan dalam bab latar belakang masalah diatas yaitu PILKADA serentak telah diresmikan pada masa keperintahan Jokowi-Jusuf Kalla dan ditetapkan dalam UndangUndang No 8 Tahun 2015.

Dalam Peraturan Pemerintah pun pada Nomor 6 Tahun 2005 tentang "Pemilihan, Pengesahan Pengangkatan, dan Pemberhentian Kepala Daerah dan Wakil Kepala Daerah adalah sarana pelaksanaan kedaulatan rakyat di wilayah Provinsi dan Kabupaten/ Kota berdasarkan Pancasila dan Undang-Undang Dasar 1945 untuk memilih Kepala Daerah dan Wakil Kepala Daerah.

Pemilukada menurut Peraturan Pemerintah Nomor 6 Tahun 2005 tentang "Pemilihan, Pengesahan Pengangkatan, dan Pemberhentian Kepala Daerah dan Wakil Kepala Daerah adalah sarana pelaksanaan kedaulatan rakyat di wilayah Propinsi dan Kabupaten/ Kota berdasarkan Pancasila dan UUD 1945 untuk memilih Kepala Daerah dan Wakil Kepala Daerah.

Undang-undang Nomor 32 Tahun 2004 pasal 56 ayat (1) dinyatakan bahwa Kepala daerah dan wakil kepala daerah dipilih dalam satu pasangan calon yang dilaksanakan secara demokratis berdasarkan asas langsung, umum, bebas, rahasia, jujur, dan adil. Pasangan calon kepala daerah dan wakil kepala daerah selanjutnya disebut pasangan calon adalah peserta pemilihan yang diusulkan oleh partai Politik atau gabungan partai politik yang telah memenuhi persyaratan.

Secara normatif, berdasarkan ukuran-ukuran demokrasi, pemilukada langsung menawarkan sejumlah manfaat dan sekaligus harapan bagi pertumbuhan, pendalaman dan perluasan demokrasi lokal. Pertama, sistem demokrasi langsung melalui pemilukada langsung akan membuka ruang partisipasi yang lebih luas bagi

11 Cakra Arbas, Jalan Terjal Calon Independen pada Pemilukada di Provinsi Aceh, (Jakarta: Sofmedia, 2012), 31. 
warga dalam proses demokrasi dan menentukan kepemimpinan politik di tingkat lokal dibandingkan sistem demokrasi perwakilan yang lebih banyak meletakkan kuasa untuk menentukan rekruitmen politik di tangan segelintir orang di DPRD (oligarkis).

Kedua, dari sisi kompetensi politik. Pemilukada langsung memungkinkan munculnya secara lebih lebar preferensi kandidatkandidat berkompetensi dalam ruang yang lebih terbuka dibandingkan ketertutupan yang sering terjadi dalam demokrasi perwakilan. Pemilukada langsung bisa memberikan sejumlah harapan pada upaya pembalikan "syndrome" dalam demokrasi perwakilan yang ditandai dengan model kompetensi yang tidak fair, seperti; praktik politik uang (money politics).

Ketiga, sistem pemilihan langsung akan memberi peluang bagi warga untuk mengaktualisasi hak-hak politiknya secara lebih baik tanpa harus direduksi oleh kepentingankepentingan elite politik seperti yang kasat mata muncul dalam sistem demokrasi perwakilan. Setidaknya, melalui konsep demokrasi langsung, warga di aras lokal akan mendapatkan kesempatan untuk memperoleh semacam pendidikan politik, training kepemimpinan politik dan sekaligus mempunyai posisi yang setara untuk terlibat dalam pengambilan keputusan politik.

Keempat, pemilukada langsung memperbesar harapan untuk mendapatkan figur pemimpin yang aspiratif, kompeten dan legitimate. Karena, melalui pemilukada langsung, kepala daerah yang terpilih akan lebih berorientasi pada warga dibandingkan pada segelintir elite di DPRD. Dengan demikian, Pemilukada mempunyai sejumlah manfaat, berkaitan dengan peningkatan kualitas tanggung jawab pemerintah daerah pada warganya yang pada akhirnya akan mendekatkan kepala daerah dengan masyarakat.

Kelima, kepala daerah yang terpilih melalui pemilukada langsung akan memiliki legitimasi politik yang kuat sehingga akan terbangun perimbangan kekuatan (check and balance) di daerah antara kepala daerah dengan DPRD. Perimbangan kekuatan ini akan meminimalisasi penyalahgunaan kekuasaan seperti yang muncul dalam format politik yang monolitik. ${ }^{12}$

\section{Metode penelitian}

Jenis penelitian yang digunakan oleh peneliti adalah penelitian kualitatif menggunakan pendekatan grounded theory, peneliti melakukan riset yang berfokus pada rangkaian peristiwa, tindakan, atau aktivitas individual maupun kolektif
12 Yusdianto, Identifikasi Potensi Pelanggaran Pemilihan Kepala Daerah (Pemilukada) dan Mekanisme Penyelesaiannya, Jurnal Konstitusi, II no. 2 (November 2010): 44. 
yang berkembang dari waktu ke waktu dalam konteks tertentu. Grounded theory berguna dalam situasi-situasi ketika sedikit sekali yang diketahui tentang topik atau fenomena tertentu. Alasan peneliti memilih pendekatan ini adalah peneliti tidak memulai penyelidikan dengan satu teori tertentu lalu membuktikannya, namun dengan suatu bidang kajian dan hal-hal yang terkait dengan bidang tersebut.

Penelitian ini dilakukan kantor KPU Kabupaten Bangkalan di Jl Re Martadinata No.1a Mlajah Bangkalan Penelitian ini menggunakan sumber data primer dan sekunder yang diperoleh menggunakan teknik pengumpulan data observasi, wawancara dan dokumentasi. Pengumpulan data dilakukan pada bulan mei 2018-desember 2018. Informan penelitian ini adalah komisioner KPU Kabupaten Bangkalan beserta salah satu Komisioner Bawaslu Kabupaten Bangkalan.

\section{Hasil dan Pembahasan}

Peneliti ini memfokuskan pada tahap strategi komunikasi KPUD Bangkalan merujuk pada hasil penyajian data yang peneliti sajikan pada sub bab sebelumnya secara mendetail dan sistematis dapat peneliti sampaikan temuan-temuan apa asaja yang diperoleh dari hasil penyajian tersebut diantaranya adalah:

\section{Pemetaan Pengetahuan Pemilih Melalui Pembagian Tipologi Khalayak}

Terdapat beberapa kelompok masyarakat yang menjadi prioroitas ikhtiar pendidikan pemilih. Ia menjadi prioritas karna posisi strategis kelompok sosial itu dalam struktur pemilih dan adanya persoalan-persoalan khusus yang perlu mendaopat perhatian dibandingkan kelompok sosial lainya. Secara umum terdapat 4 (empat) kluster pemilih yang menjadi kelompok sasaran, yaitu:

a. Kelompok Pemilih Strategis

Kelompok pemilih strategis adalah kelompok pemilih yang karena besaran ataupun posisis dalam struktur pemilih berada dalam posissi strategis. Kluster ini terbagi dalam pra-pemilih, pemula, perempuan, marginal dan penyandang stabilitas, dan agamawan.

b. Pemilih Pemula

Pemilih pemula adalah mereka yang memasuki usia memilih dan yang akan menggunakan hak pilihnya untuk pertama kali dalam pemilu/pemilukada. Denagan siklus pemilihan di Indonesia yang gelar setiap lima rtahun sekali maka kisaran usia pemilih ini adalah 12-21 tahun. mereka yang sedang menempuh pendidikan tinggi dan pekerja muda, atau dengan kata lain lulusan SMA.

c. Perempuan

Pemilih perempuan adalah warga Negara Indonesia (WNI) yang berjenis kelamin perempuan dan telah memasuki usia untuk memilih atau telah menikah. Namun perempuan dalam perspektif pilkada dan demokrasi tidak semata-mata mengacu pada aspek biologis, melainkan sosial budaya dan 
psikologis atau perspektif gender. Pemilih perempuan rentan dimobilisasi baik ketika pilkada maupun di luar pilkada.

Pemilih perempuan menjadi sasaran strategis karena berbagai alasan. Pertama, jumlah pemilih perempuan berimbang dengan pemilih laki-laki namun kapasitasnya masih terbatas dibandingkan laki-laki. Kedua, pemilih perempuan rentan dimobilisasi baik ketika pilkada maupun di luar pilkada. Ketiga, tingkat pendidikan perempuan ratarata lebih rendah dari laki-laki. Keempaat, pemilih perempuan lebih banyak memainkan peran-peran domistik sehingga urusan publik terabaikan padahal banyak menyangkut kepentingan kaum perempuan.

d. Kelompok Marginal Dan Penyandang Disabilitas

Kelompok pemilih marjinal dan penyandang disabilitas adalah suatu kelompok yang terasimilasi tidak sempurna dalam masyarakat. Kelompok marginal tercipta sebagai imbas dari perubahan structural di masyarakat yang menghasilkan residu seperti kemiskinan, keterbelakangan dan ketertindasan. Pembangunan yang tidak adil, bias kelas dan geografis, dan sebagainya menjadi penyebab lahirnya kelompok marginal. Keadaan pada kelompok marginal dan penyandang disabilitas kemudian membawa dampak pada kesadaran politik yang mereka miliki.

Melihat konsidi sosial budaya yang ada di Kabupaten Bangkalan, maka KPUD kabupaten bangklana melakukan beberapa upaya untuk meningkatkan partisipasi masyarakat (pemilih) Pemilu 2014 di Kabupaten Bangkalan merupakan kegiatan yang dilaksanakan pada bulan Juli-Agustus 2015 bersifat evaluasi terhadap pelaksanaan proses demokrasi yang dilaksanakan di daerah oleh KPUD. Bahan evaluasi ini akan menjadi pertimbangan dalam menyusun strategi kedepan KPUD dalam rangka meningkatkan partisipasi masyarakat/pemilih. Beberapa hal yang menjadi poin penting dalam penelitian ini adalah; Pertama, faktor-faktor penyebab menurunnya tingkat partisipasi masyarakat/pemilih dalam pemilu maupun pemilukada di Kabupaten Bangkalan karena faktor sosialisasi yang dilakukan oleh KPUD yang kurang efektif dan komuniatif, selain itu belum dilakukan secara menyeluruh. Sosialisasi yang baik akan menggugah kesadaran calon pemilih untuk menggunakan haknya dalam Pemilu. Kedua, faktor kandidat atau figur. Khususnya Pemilu untuk DPR dan DPRD kandidatnya lebih banyak dan lebih dekat dengan calon pemilih dibandingkan dengan kandidat dalam Pemilu Presiden.

Sementara Pemilu Presiden hanya digerakkan oleh tim suksesnya saja. Ketiga, Pemilih sudah semakin cerdas dalam menentukan siapa calon 
pemimpinnya, sehingga ketika terdapat calon yang kurang bisa diterima oleh masyarakat maka akan mempengaruhi antusiasme masyarakat dalam mengikuti pemilu/pemilukada. Faktorfaktor penyebab Golput selalu hadir dalam setiap Pemilu dan Pemilukada adalah Pertama, Problem Struktural, seperti adanya DPT ganda, adanya orang yang sudah meninggal dunia tetapi masih tercatat dalam DPT, dan adanya orang-orang yang belum tercatat dalam DPT. Kedua, pemilih tidak menggunakan hak pilihnya karena terbentur dengan jam kerja. Ketiga, pilihan rasional, dimana para pemimpin dianggap tidak ada yang sesuai dengan yang diharapkan. Kempat, faktor pendidikan politik pemilih, bahwa semakin tinggi pemahaman pendidikan politik warga negara, biasanya angka golputnya semakin naik.

\section{Pemilihan Media Yang lebih Bersifat Konvensional}

Penggunaan Teknologi Informasi Hampir tidak ada masyarakat yang tidak bersentuhan sama sekali dengan teknologi informasi. Pada saat bersamaan, teknologi informasi juga berkembang dengan cepat. Situasi tersebut perlu direspon dengan baik untuk pendidikan pemilih. Teknologi informasi memiliki daya jangkau yang sangat luas dan akses real time.

Internet, gadget, sistem aplikasi, teknologi visual, audio-visual dan sebagainya saat ini begitu dekat dengan berbagai lapisan masyarakat. Melalui itu berbagi informasi berupa data, suara, gambar dan video dapat diperoleh dengan cepat, mudah dan murah. Hampir tidak ada masyarakat yang tidak tersentuh oleh kehadiran teknologi informasi.

Pendidikan pemilih dengan memanfaatkan teknologi informasi kontemporer akan mendorong partisipasi. Pemilih akan terdorong berkontribusi dan memberikan umpan balik atas topik atau masalah yang sedang menjadi pembahasan bersama, atas kesadaran sendiri. Pendidikan pemilih juga menjadi lebih transparan dan dapat dijangkau oleh semua pihak dan sepanjang waktu. Konektivitas dan jejaring antar sesama pengguna yang terlibat dalam pendidikan pemilih juga dapat tercipta dengan memanfaatkan teknologi informasi.

Lebih jauh lagi, pemanfaatan teknologi informasi kontemporer untuk pendidikan pemilih dapat mendorong suatu advokasi publik atas suatu persoalan. Setiap orang bebas menyuarakan ide atau kepentingannya sekaligus meminta dukungan.

Namun demikian, pemanfaatan teknologi tak selamanya dapat dirasakan jika khalyak belum bisa menerima kecanggihan teknologi secara utuh, di Kabupaten Bangkalan misalnya, setiap pesan lebih bermakna dan efektif tersampaikan jika melalui tatap muka. Hal itu lebih cenderung berhasil mengingat budaya dan adat masyrakat yang masih dibilang baru berkembang kearah modern.

Meskipun sifatnya sangat konvensional, media massa masih 
menjadi salah satu wahana yang efektif sebagai penyampai informasi kepada pemilih. Ia mampu menjangkau pelbagai lapisan masyarakat secara massif tanpa terkecuali. Media massa berperan penting dalam melaksanakan pendidikan pemilih guna mencerdasan warga negara dan menyebarkan nilainilai demokrasi.

Secara umum, media massa dapat dibagi ke dalam dua kelompok, yaitu media cetak dan media elektronik. Media cetak berupa koran, majalah, tabloid, dan sejenisnya. Sedangkan media eletronik adalah televisi, film, video, dan radio.

Media massa dengan fungsi persuasif mampu membentuk kesadaran pemilih. Ia mampu mempengaruhi opini pemilih atas berbagai persoalan yang berkembang. Media massa dapat mengubah budaya politik dan partisipasi politik pemilih.

\section{KPUD Junjung Netralitas Sebagai Penyelengara}

Dalam banyak kasus, pemicu konflik pada tahapan pemilihan umum (pemilu) di Indonesia adalah faktor integritas dan ketidaknetralan penyelenggara pemilu. Sehingga menimbulkan rasa ketidakpercayaan maupun ketidakpuasan peserta pemilu terhadap lembaga penyelenggara.

Untuk menghindari kondisi tersebut, terhadap menipisnya rasa loyalitas, dedikasi dan kinerja penyelenggara dalam pelaksanaan tugas, serta untuk menjaga kondisi terdegradasinya rasa kedisiplinan dan kepatuhan unit-unit satuan kerja penyelenggara dalam melaksanakan peran serta tanggung jawab kerjanya, diperlukan suatu ketegasan dan sikap arif dari setiap aparatur penyelenggara pemilu untuk bersikap netral.

Asas netralitas penyelenggara pemilu tersebut menjadi sangat penting terutama dikaitkan dengan dalih-dalih hukum yang menegaskan afiliasi politik bagi para penyelenggara pemilu. Tidak mengherankan, bahwa netralitas penyelenggara pemilu diperlukan, tanpa harus menghilangkan hak-hak politiknya sebagai warga negara. Bilamana norma atau hukum yang mewajibkan netralitas bagi penyelengggara pemilu dikaitkan pada penerapan faktualnya, maka akan ditemukan suatu indikator menarik.

Artinya, semua gagasan baik yang tertuang secara normative dalam undang-undang ataupun gagasan keberpihakan penyelenggara selalu menjadi sorotan baik di mata public maupun pengawas pemilu. Dalam hal inni KPUD Kabupaten Bangkalan sudah bersikap netral baik dari sisi aturan main perundang-undangan atau bahkan secara keberpihakan perorangan.

Melihat pengalaman Pilkada 2012, para kandidat calon bupati dan wakil bupati berjuang secara individu meraih suara sebanyak-banyaknya. Hal ini membuat para kandidat menghalalkan segala cara untuk mendapatkan suara, termasuk dalam 
hal pendanaan kampanye serta manuver politik. Tidak jarang terjadi persaingan antar caleg dan berpotensi memicu konflik, baik antar caleg satu partai maupun caleg beda partai. Pemilu yang berkualitas dapat dilihat dari dua sisi, yaitu sisi proses dan sisi hasil. Apabila dilihat dari sisi proses Pemilu dapat dikatakan berkualitas jika Pemilu tersebut berlangsung secara demokratis, jujur, adil, serta aman, tertib, dan lancar. Sedangkan apabila Pemilu dilihat dari sisi hasil, Pemilu dapat dikatakan berkualitas jika Pemilu tersebut dapat menghasilkan wakil-wakil rakyat, dan pemimpim negara yang mampu mewujudkan cita-cita nasional, sebagaimana tercantum dalam Pembukaan UUD Negara Republik Indonesia Tahun 1945 dan mengangkat harkat dan martabat bangsa dan negara di mata masyarakat Internasional.

\section{Kesadaran Politik Masyarakat Yang Rendah Sebagai Penghambat Kinerja KPUD}

Tradisi carok di dalam masyarakat Madura sebagai upaya penyelesaian konflik dengan cara kekerasan. Apakah dengan melukai seseorang dengan luka berat sampai pada bentuk pembunuhan sangat terkait erat dengan hasrat dan rasa menjaga kehormatan dan harga diri. Orang Madura akan melakukan carok bila harga diri dan kehormatannya merasa terusik, diganggu atau dilukai. Rasa terusik bila itu berkembang pada perasaan malu, atau dalam bahasa Maduranya maloh atau todus akan bermuara pada tindakan carok. Bahasa Madura yang popular menegaskan dalam konteks ini adalah 'ango'an pote tolang etembang pote matah', artinya lebih baik putih tulang dibandingkan putih mata. 'Hidup itu tidak ada maknanya kalau kehilangan harga diri',

Masyarakat Madura seorang yang memiliki pengetahuan yang lebih tentang agama Islam dibanding orang kebanyakan seperti Kyai atau Ustadz. Mereka akan lebih cenderung pada apa yang ustadz atau kyai itu katakan dan suruh. Pemerintah setempat meskipun ada namun, seolah-olah tidak ada kecuali yang berada pada pemerintahan itu adalah para ustadz atau kyai. Karena pemerintahan itu hanya sebatas formalitas.

Dengan begitu, masyarakat Madura seperti halnya Bangkalan menganggap Pemerintah adalah sebagai urutan ketiga setelah guru dan orang tua. Dengan budaya semacam itu, proses pemilihan kepala daerah, legisltif maupun presiden tak lebih seperti perayaan seremonial belaka bagi masyarakat. Dengan kondisi demikian Komisi pemilihan umum sebagai penyelenggara mempunyai tugas yang cukup kompleks dalam menyakinkan dan memberi pemahaman kepada masyarakt tentang penting demokrasi dan pemilihan umum.

Dengan begitu, kinerja Komisi pemilihan umum daerah menjadi 
bagian paling urgen dalam setiap momen pergantian pemimpin di daerah. Dari paparan data yang telah disajikan sebelumnya, KPUD Bangkalan berusaha memilah tipollogi pemilih sesuai dengan perilakunya, terlebih KPUD Bangkalan berusaha menselaraskan setiap sosialisasi yang dilakukan dengan cara menyesuaikan dengan budaya dan kebiasaan yang ada di Kabupaten Bangkalan. Maka dari itu langkah yang dilakukan sialah memetakan segmentasi dalam masyarakat. Segmentasi adalah pembilahan social yang ada di dalam masyarakat. Masyarakat terpilah-pilah kepada kelompok-kelompok pemilih yang homogeny yang potensial, hal itu tentu berdasarkan database kependudukan atau daftar pemilih tetap.

Setiap segmen pemiilih memiliki kebutuhan, karakteristik, perilaku, yang berbeda. Oleh karena itu pendekatan pendidikan pemilih yang dilakukan kepada masingmasing kelompok tersebut harus berbeda dengan karakter dari setiap segmen. Setelah itu, penguatan karakter pemilih akan diarahkan kepada pemilih. Berorientasi kepada pemilih artinya kepentingan pemilih sebagai warganegara menjadi pusat penguatan. Pemilih harus dikuatkan di hadapan pemerintah dan elemen nondemokrasi lainya.

Strategi KPUD Bangkalan dalam meningkatkan partisipasi pemilih ialah Minimnya kesadaran politik yang ada di Kabupaten
Bangkalan. Hal itu diPerilaku masyarakat termasuk didalamnya perilaku politik dengan sendirinya berkembang didalam dan dipengaruhi oleh kompleksitas nilai-nilai budaya yang ada didalam masyarakat tersebut. Pengaruh ini dapat dilihat dari penerapan nilai-nilai tradisi dalam sistem kebudayaan tersebut yang dilaksanakan oleh sebagian besar masyarakat, terutama didalam struktur masyarakat yang semua anggotanya tercakup di dalam kekuatan sosial yang sama dimana komunitas atau masyarakat yang ada di Kabupaten Bangkalan.

Dalam penelitian ini, peneliti menggunakan teori diantaranya teori perencanaan strategi model John Middeleton untuk menganalisis hasil temuan penelitian melalui teori diatas. Hasil dari temuan peneliti yang sudah ditetapkan sebelumnya dicari relevansinya dengan teori-teori yang ada, sehingga ditemukan sebuah jawaban yang relevan dengan teori.

Berdasarkan teori tersebut, KPUD Bangkalan Dari hasil penelitian, strategi komunikasi KPUD bangkalan dalam meningkatkan partisipasi pemilih. Perencanaan komunikasi yang dimaksud adalah untuk memperhatikan dan menentukan komponen-komponen komunikasi serta meminimalisir faktorfaktor penghambat pada setiap komponen tersebut dalam hal untuk mewujudkan tujuan dari sosialisasi ppeningkatan partisipasi pemilih di Kabupaten Bangkalan. Selain dalam rangka 
peningkatan partisipasi pemilih dalam konteks sosialisasi pemilihan kepala daerah lebih jauh lagi sosialisasi dan persuasive ditujukan untuk meningkatkan pemahaman dan pengetahuan masyarakat mengenai kesadaran politik di Kabupaten Bangkalan.

Secara garis besar penelitian ini menggunakan penerapan strategi komunikasi model John Middleton. Artinya sebelum merancang strategi dalam menigkatkan partisipasi pemilih, KPUD harus menetapkan database atau yang lumrah disebut dengan daftar pemilih tetap.

Di Tahun 2012 dengan jumlah Daftar pemilih tetap sebanyak 888.928 suara, Sementara pada Tahun 2018, jumlah daftar pemilih tetap memang terbilang menurun, alasanya tentu tingkat populasi masyarakat yang berkurang berdasarkan data dari dinas kependudukan dan catatan sipil setempat. sebanyak 859.067 pemilih tercatat dalam data KPUD Kabupaten Bangkalan. Jika merujuk pada model komunikasi john middleton. Promosi atau kampanye haruslah berdasarkan kepada database assasement. Artinya promosi atau kampanye yang dilakukan tidak bisa dilakukan kepada khalayak umum dalam arti di ruang lingkupi oleh teritori wilayah.

Setelah menentapkan database atau DPT. KPUD kemudian mulai memetakan segmentasi pemilih menurut pada tipologi dan karakteristik pemilih, dengan begitu KPUD bangkalan dapat menentukan cara yang akan dipilih dalam menentukan model pendekatan kepada pemilih. Upaya meningkatkan partisipasi pemilih, secara operasional dapat ditelusuri dari beberapa kondisi di sekitar "golput" dan memadukannya untuk mencari titik temu secara operasional, yaitu:

Kondisi yang menjadi masalah / penyebab kurangnya atau rendahnya partisipasi pemilih.Lini partisipasi pada segmentasi pemilih rentan : pemilih pemula, swing voters, pemilih usia lanjut, mereka yang kurang akses informasi, kaum "golput".

Stakeholders aktif, yakni "siapa yang berkepentingan dengan partisipasi pemilih". Ketiga variabel di atas perlu ditelusuri sambil mengenali secara tepat:

a) Karakter pemilih

b) Nilai-nilai budaya lokal

c) Mendekatkan pemilih pada isu kemanfaatan pemilu

Ketiganya dimaksudkan agar terbentuk konstruksi berpikir pada masyarakat bahwa pemeranannya dengan ikut pemilu secara aktif (sebagai pemilih) adalah memang kepentingan dan kebutuhannya (bukan sekedar hak atau wajib). Pertama mencari penyebab kurang/ rendahnya partisipasi. Dari penelitian penulis di atas, beberapa faktor di sekitar rendahnya apresiasi terhadap pemilu yang kemudian merembes kepada menjauhnya dari urusan pemilu, adalah, pragmatisme masyarakat yang kemudian mengukur aktivitas pemilu dan aktivitas elektoral peserta pemilu dari sudut pandang kepentingan mereka (yang kerap bernilai pragmatis). Kedua, bertolak dari rendahnya apresiasi terhadap pemilu. Ini adalah persepsi negatif pemilih terhadap “apa dan siapa yang akan dipilih". Ketiga, mendekatkan jarak politik dan ikatan sosial pemilih dengan peserta pemilu. Faktor informasi (misalnya kelangkaan informasi 
tentang pemilu) tidak serta merta menjauhkan masyarakat dari keputusannya untuk ikut pemilu, namun berada pada dataran pemahaman materi pemilu saja. Dari sisi partisipasi pemilu, tidak mengkhawatirkan, justru dari sisi kepentingan peserta pemilu yang mengkhawatirkan, karena kelangkaan informasi pemilu bisa membiaskan pemilih seperti salah pilih dsb.

Ketiga poin di atas sekaligus bisa mengikis persepsi publik terhadap isu pemilu (bagian dari isu politik), bahwa urusan pemilu yang dipersepsi sebagai urusan elit (bukan urusan rakyat) menjadi bagian dari kehidupan rakyat. Sayangnya, isu politik masih dianggap "horor", sulit, tidak terjangkau, tingkat tinggi, penuh tiputipu. Dan itu urusan elit. Nah. Mengubah persepsi ini yang semestinya menjadi isu utama pendidikan politik dan pendidikan pemilih.

Hal itu kemudian menjadi ssalah comeen isu yang menjadi dasar dari perumusan strategi KPUD kabupaten bangkalan dalam rangka meningkatkan partisipasi pemilih. Jika merujuk pada langkah-langkah strategi komunikasi model john middlethon, Pengumpulan data base line dan need assessment. Pengumpulan data base line menjadi hal yanng sangat penting dalam perencanaan komunikasi. Setiap aspek perencanaan akan mengacu pada data base line atau penelitian. Kegiatan penelitian ini akan dihasilkan data primer dan data sekunder. Dalam hal ini KPUD kabupaten bangkalan sudah melakukan proses data base line dan need assessment dalam bentuk pendataan daftar pemilh tetap (DPT).
Setelah itu, Penentuan tujuan bisa dilakukan dengan memperhatikan masalah yang dihadapi dan akhirnya merumuskan bagaimana keadaan masalah tersebut setelah program dilaksanakan. Penentuan tujuan harus spesifik supaya dengan jelas dan komprehensif bisa dilaksanakan. Kemudian objective dari sebuah program haruslah terukur apalagi saat dilakukan evaluasi. Kemudian objective harus bisa dijangkau dengan sumberdaya yang ada. Objective kemudian harus realistis sesuai dengan waktu yang tersedia dan budget yang ada beserta sumber daya lain, dengan kata lain francangan awal formulasi strategi dapat dilakukan setelah perumusan selesai.

Strategi adalah cara yang disusun seefektif dan seefisien mungkin untuk mencapai objective yang ditentukan. Strategi ini merupakan dasar dari taktik yang akan dibuat dalam setiap keadaan di lapangan.

Analisis dan segmentasi khalayak juga harus dilaksanakan dengan menentukan siapa target sasaran program yang sedang dijalankan. Analisis ini sangat penting karena bentuk perencanaan akan sangat bergantung pada tipe publik yang dihadapi. Pemrogram komunikasi setidaknya harus memilah publik menjadi tiga kelompok. Pertama, Latent Public yaitu kelompok yang menghadapi masalah dan tetapi tidak mempunyai perhatian lebih. Kedua, adalah aware public, yaitu kelompok yang bertanggung jawab terhadap masalah. Sedangkan yang terakhir adalah active public yaitu kelompok yang melakukan tindakan terhadap masalah, seperti 
memetakan tipologi pemilih melalui kecenderungan khalayak.

Pemilihan media sangat penting dilakukan dengan memperhatikan tiap tahap berikut ini.Pertama mendaftar media yang sudah ada. Semua media yang mungkin mendukung program komunikasi di data dan bila perlu dikelompokkan menurut keperluan program. Setelah pendataan dilakukan evaluasi, media mana saja yang sesuai dari segi waktu, jangkauan segment, biaya, dan efektifitas.

Pendesainan dan pengemasan pesan lantas dilakukan sesuai dengan penelitian yang dilakukan, segment dan berpanduan pada teori-teori dan keilmuan yang ada. perancangan struktur manajerial beserta job deskripsi masing-masing. Mekanismemekanisme perlu disiapkan dalam hal ini misal, bagaimana alur dana berjalan. Selain itu bagaimana koordinasi dilakukan dilapangan, dan sebagainya.

Setelah perumusan strategi beserta anlaisis dilakukan KPUD Kabupaten bangalan kemudian mengimplementasi rumusan strategii dengan program yang telah ditentukan. Beberapa hal yang umum dilakukan adalah melakukan lobby-lobby, silaturahmi, dan sosialisasi. Pembentukan sistem pengontrol di lapangan juga biasanya dilakukan dengan menggunakan sumber daya masyarakat sendiri. Tentunya hal ini bergantung pada lobby-lobby yang telah dilakukan tersebut.

Evaluasi Program dibutuhkan untuk melihat apa saja tindakan dalam program yang tepat dan mana yang tidak sehingga ke depannya bisa dilakukan program yang lebih baik. Evaluasi bisa dibagi menjadi dua yaitu evaluasi ongoing dan end review.
Evaluasi ongoing dilaksanakan selama proses berlangsung dan akan menjaga fleksibilitas sebuah program. Sedangkan end review mencakup semua evaluasi dari awal sampai akhir yang akan merangkum semua evaluasi ongoing dan perbaikannya sehingga bisa dijadikan pijakan untuk pelaksanaan program berikutnya.

\section{Kesimpulan}

Dari yang telah diuraikan oleh peneliti da lam penelelitian di atas maka dapat diambil kesimpulan tentang, bagaimana strategi Strategi KPU Kabupaten Bangkalan dalam upaya meningkatkan partisipasi pemilih masyarakat pada pilkada antara lain. Strategi atau upaya yang dilakukan KPU kabupaten Bangkalan dalam meningkatkan Partisipasi Pemilih pada Pemilihan Bupati dan Wakil Bupati antara lain:

1 Strategi Sosialisasi Politik merupakan salah satu cara yang dilakukan KPU untuk meningkatkan partisiasi pemilih yaitu dengan metode sosialisasi tatap muka (face to face) dan melalui media. Dalam hal ini kegiatan yang dilakukan pertemuan dengan tokoh msyarakat, tokoh pemuda, kelompok perempuan dan kelompok mahasiswa. Untuk media yang digunakan adalah media cetak, media masa dan media elektronik.

2 Strategi Pendidikan Pemilih Pemula merupakan salah satu metode KPU dengan memberikan perhatian secara khusus kepada pemilih pemula, dalam hal ini adalah para pelajar yang duduk di bangku SLTA sederajat, dengan menggandeng Pemilih Pemula. 
3 Strategi Penguatan Kelembagaan yaitu salah satu cara atau metode yang dilakukan KPU untuk memperkokoh atau memperkuat badan atau lembaganya guna menghasilkan kinerja yang baik, sehingga tujuan sebagai penyelenggara dalam rangka meningkatkan partisipasi pemilih akan sesuai yang diinginkan. Strategi ini dalam penerpannya dengan meningkatkan kapasitas dan kualitas penyelenggara dalam hal ini adalah PPK, PPS dan KPPS dan meningkatkan komunikasi dan keterbukaan informasi KPU kepada Publik.

\section{Daftar Pustaka}

Abdullah, Rozali. Mewujudkan Pemilu yang Lebih Berkualitas. Pemilu Legislatif. Jakarta: PT. Raja Grafindo Persada, 2009.

Arbas, Cakra. Jalan Terjal Calon Independen pada Pemilukada di Provinsi Aceh. Jakarta: Sofmedia, 2012.

Bakker, Anton dan Achamad Charis Zubair. Metodologi Penelitian Filsafat. Yogyakarta: Kanisius, 1990.

Cangara, Hafied. Perencanaan Dan Strategi Komunikasi. Jakarta: PT. Raja Grasindo, 2008.

Effendy, Uchjana Onong. Ilmu Komunikasi Teori dan Praktek. Bandung: Remadja Karya, 2002.

Hadi, Sutrisno. Metodologi Researh. Yogyakarta: Andi Offset, 1989. jpnn.com. "jelang-coblosan-polisi-massabentrok", diakses 20 September 2018.

https://pilkada.jpnn.com/news/jelangcoblosan-polisi-massa-bentrok pada 20-09-2018

Kartodirjo, Sartono. Pengantar Sejarah Indonesia Baru, 1500-1900, dari Emperium Sampai Imperium, jilid 1. Jakarta: Gramedia Pustaka Utama.

Kumolo, Tjahjo. Politik Hukum Pilkada Serentak. Jakarta: Mizan Republika, 2015.

Mulyana, Dedy. Ilmu Komunikasi Suatu Pengantar. Bandung: Remaja Rosdakarya, 2010.

Obert John Voll. Politik Islam: Kelangsungan dan Perubahan di Dunia Modern, terj. Ajat suderajat. Yogyakarta: Titian Ilahi Press, 1994.

Ritzer, George. Sociology: A Multiple Paradigm Science. Boston: Allyn and.

Rozaki, Abd. Menabur Karisma Menuai Kuasa, Kiprah Kiai Dan Blater Sebagai Rezim Kembar Di Madura. Yogyakarta: Pustaka Marwa, 2004.

Saukah, Ali. Pedoman Penulisan Karya Tulis Ilmiah. Malang: Ikip Malang, 2000.

Sudarto. Metode Penilitian Filsafat. Jakarta: Raja Grafindo Persada, 1997.

Surakhman, Winarno. Pengantar Penelitian Ilmiah. Bandung: Tarsito, 1994

Takdir, Alisyahbana S. Values as Integrating Forces in Personality, 
Society and Culture. Kuala Lumpur: University Of Malay Press,1997.

Turner, Bryan S. Sosiologi Islam: Suatu

Telaah Analisis Atas Tesa Sosiologi

Weber, terj. GA Ticolu. Jakarta: Raja

Grafindo Persada, 1994.

Yusdianto, Identifikasi Potensi

Pelanggaran Pemilihan Kepala Daerah

dan Mekanisme PenyelesaiiannyaI.

Jurnal Konstitusi II no. 2. November, 2010: 40-55. 